\title{
Quantification of Ecosystem Services Provided by Pterocarpus lucens Lepr. Ex Guill. and Perrott.: Forage Production, Timber and Carbon Sequestration in the Biosphere Reserve of Ferlo (Northern Senegal)
}

\author{
Daouda Ngom ${ }^{1,2 *}$, Emile Codjo Agbangba ${ }^{1,2}$, Thioro Fall' ${ }^{1}$, Sekouna Diatta ${ }^{2}$, \\ Léonard E. Akpo ${ }^{2}$ \\ ${ }^{1}$ Department of Agroforestery, Unité de Formation et de Recherche de Sciences et Technologie (UFR ST), \\ University Assane Seck of Ziguinchor, Ziguinchor, Senegal \\ ${ }^{2}$ Department of Plant Biology, Faculty of Science and Technology, University Cheikh Anta Diop of Dakar, Dakar, \\ Senegal \\ Email: $\underline{\text { ngom daouda@yahoo.fr }}$
}

Received 11 January 2014; revised 26 February 2014; accepted 18 March 2014

Copyright (C) 2014 by authors and Scientific Research Publishing Inc.

This work is licensed under the Creative Commons Attribution International License (CC BY).

http://creativecommons.org/licenses/by/4.0/

(c) (i) Open Access

\begin{abstract}
This study aims at quantifying the most important ecosystem services: forage production, timber production and carbon sequestration provided by Pterocarpus lucens to local communities of Ferlo Biosphere Reserve. The results suggested that the ecological structure of Pterocarpus lucens revealed a bell-shaped form with left dissymmetric distribution indicating a predominance of individuals with small circumference and height. A regression using the software Minitab 16, with circumference and the height as explanatory variables, has allowed a development of predictive models for the estimation of the produced forage and the quantification of the timber supplied by one of the most used plant species in Sahelian pastures. Forage production of Pterocarpus lucens was estimated at $178 \mathrm{~kg} \mathrm{DM} / \mathrm{ha}$. This large value of forage showed the predominance of this species in animal feed in the Sahel. The quantity of wood produced was $545 \mathrm{~kg} \mathrm{DM} / \mathrm{ha}$ while the quantity of above ground sequestered carbon was $325.35 \mathrm{~kg}$ of $\mathrm{C} / \mathrm{ha}$. Those estimations are interesting in the implementation context of the Ferlo Biosphere Reserve which aims at matching the productive capacity of ecosystems with the needs of local communities.
\end{abstract}

${ }^{*}$ Corresponding author.

How to cite this paper: Ngom, D., et al. (2014) Quantification of Ecosystem Services Provided by Pterocarpus lucens Lepr. Ex Guill. and Perrott.: Forage Production, Timber and Carbon Sequestration in the Biosphere Reserve of Ferlo (Northern Senegal). American Journal of Plant Sciences, 5, 766-777. http://dx.doi.org/10.4236/ajps.2014.55091 


\section{Keywords}

\section{Ecosystem Services; Regression; Forage; Timber Production; Carbon Sequestration}

\section{Introduction}

Biosphere reserves have a primary function of reconciling conservation and sustainable use of ecosystem services for the subsistence of communities. Different types of ecosystems or species assure different functions and services. In the Sahelian ecosystems of Ferlo, ligneous forage in general and Pterocapus lucens in particular plays an ecological and socio-economic importance. Indeed, herbaceous resources are insufficient to ensure a proper feed balance throughout the annual cycle; trees are the only recourse for farmers to ensure the survival of animals during the lean period. They help to maintain the balance of fragile ecosystems by increasing the structure and recycles soil nutrients [1] [2]. Pterocarpus lucens is one of the two most palatable species to livestock, but also the most pruned by the shepherds in the pastoral zone of Ferlo. It contributes to the production of wood and it is the most used species as timber service to local communities [3]. This species also has a high potential for carbon sequestration. The syntheses of knowledge on the productivity of savannas [4]-[8] have revealed the complexity of the task and the diversity of responses that can be carried out while dealing with the productivity of savannas [9]. Thus, for a better estimation of the production of tree and shrub formations, it is necessary to find methods that take into account the different productions, diversity and dynamics of woody vegetation [10]. Those estimations are necessary to establish a precise balance between the needs and resources, particularly with regard to firewood [4]. The current study carried out in the Biosphere Reserve of Ferlo (Northern Senegal) aimed at quantifying the forage and timber production of Pterocarpus lucens and its carbon sequestration.

\section{Material and Methods}

\subsection{Site Location}

The study was undertaken in the rural community of Velingara-Ferlo in the northern Senegal $\left(14^{\circ} 24^{\prime} \mathrm{N}-16^{\circ} 11^{\prime} \mathrm{N}\right.$ latitude and $13^{\circ} 07^{\prime} \mathrm{W}-14^{\circ} 51^{\prime} \mathrm{W}$ longitude) (Figure 1). It is situated between the administrative regions of Matam, Louga and Saint-Louis. Three main ethnic groups prevailed (Peuls, Wolofs and Moors) with a more dominance of Peuls. Ferlo is established on sandy dune formations of the continental terminal. The landscape is marked with slopes lower than 3\% [11] affecting evolution of the mediums and discriminated three main types of soil: sandy soils, a gradient of clayed-sandy to clayed soils and lateritic soils. The climate is sudano-sahelian characterized by a three-month rainy season with high thermal amplitude. The maximum temperature reached $40.4^{\circ} \mathrm{C}$ in May. The annual average temperature is $28.6^{\circ} \mathrm{C}$ while the minimal monthly average temperatures are $14.1^{\circ} \mathrm{C}$ in January.

Precipitations are concentrated in July, August and September. The Ranerou rain station averaged $474 \mathrm{~mm}$ (from 1951 to 2011). Since 1970, more than $25 \%$ of the annual rain is lower than the dry inter-annual mean value as these years belong to the driest ones. Chorologically, the biosphere reserve holds both sahelian formations and sudanian savannas. The woody layer is dominated by shrubs with mainly Combretum glutinosum, Pterocarpus lucens, Guiera senegalensis, Grewia bicolor, Acacia Senegal, Balanites aegyptiaca, etc. The herbaceous layer is marked by grass species such as Cenchrus biflorus, Schoenfeldia gracilis, Eragrostis tremula and Dactyloctenium aegyptium.

\subsection{Plant Material}

The plant material used is Pterocarpus lucens (Photo 1). It is a shrub or small tree up to $12 \mathrm{~m}$ exceptionally high, which grows in very dry areas where development depends on the nature and depth of the soil [12]. The leaves are alternate, odd-pinnate and flowering occurs in dry season, just before or at the time of leafing. This is a species that occurs in the Sahel-Sudanian savannas in Sudanese from Senegal to Ethiopia [13]. It's a major forage species in the pastoral zone of Senegal.

The population structure was established on the exhaustive list of 57 plots of $30 \times 30 \mathrm{~m}\left(900 \mathrm{~m}^{2}\right)$ basis [14]. On each timber, we measured the circumference of the trunk at $0.30 \mathrm{~m}$ above the ground [15], total height, the 


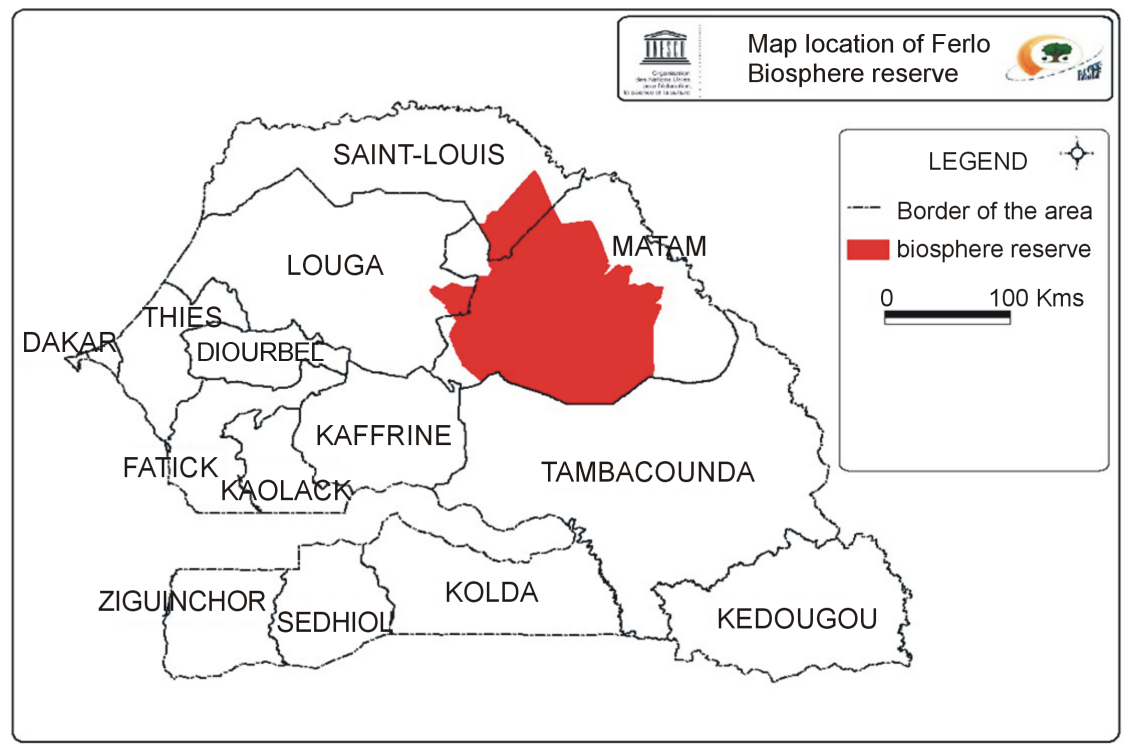

Figure 1. Map of the biosphere reserve of ferlo.

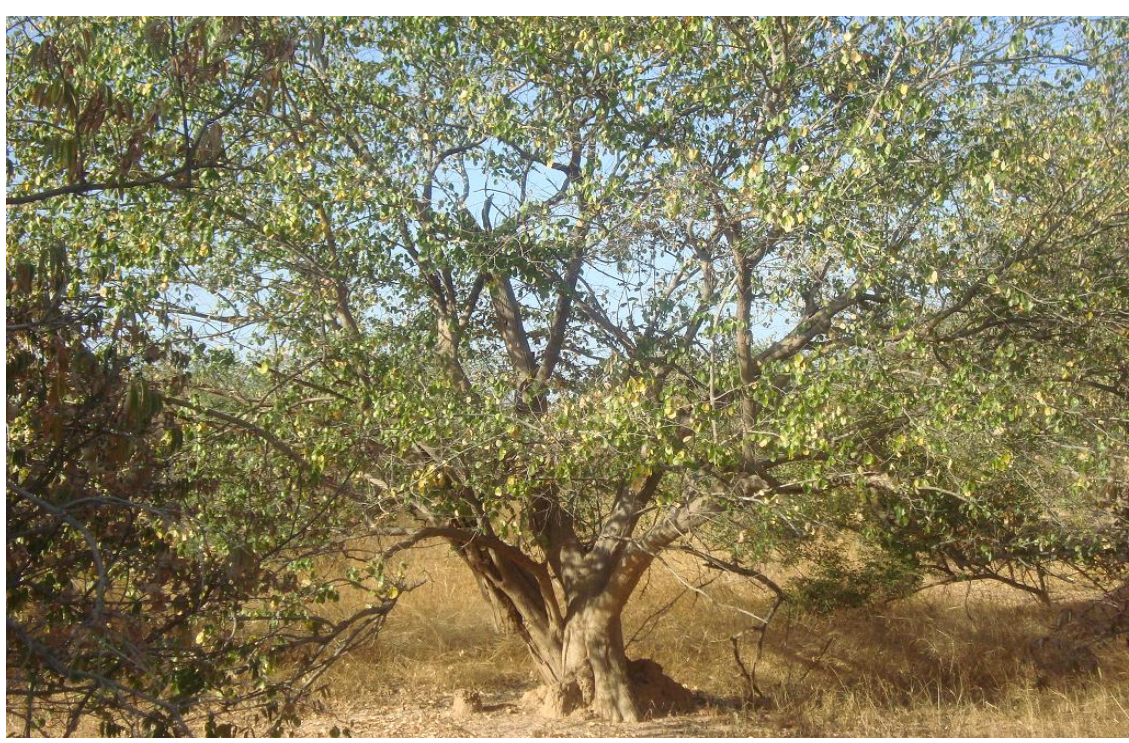

Photo 1. Pterocarpus lucens.

height at the first branch, the diameter (North-South, East-West) of the crown. In order to avoid damages to sampled trees, we chose different types of branches to represent the tree. For each branch, we measured length and circumference. Then we collected all the leaves and cut the wood into discs. All harvested leaves and cut wood discs are put in a bag and weighed (Figure 2) using a spring balance. Data collection was conducted in September 2011. Samples were collected (leaves and discs of wood) on 40 trees and returned to the laboratory to determine the dry matter after oven drying at $85^{\circ} \mathrm{C}$ to constant weight. This method allowed establishing regression equations to link leaf phytomass to the basal circumference and length of the corresponding branches [16] at one hand and the amount of wood with the same dimensional parameters at other.

\subsection{Statistical Analysis}

Pterocarpus lucens trees distribution within population was adjusted to the Weibull function, commonly nowadays used in forestry surveys [17]-[20].

The Weibull distribution is as follows: 


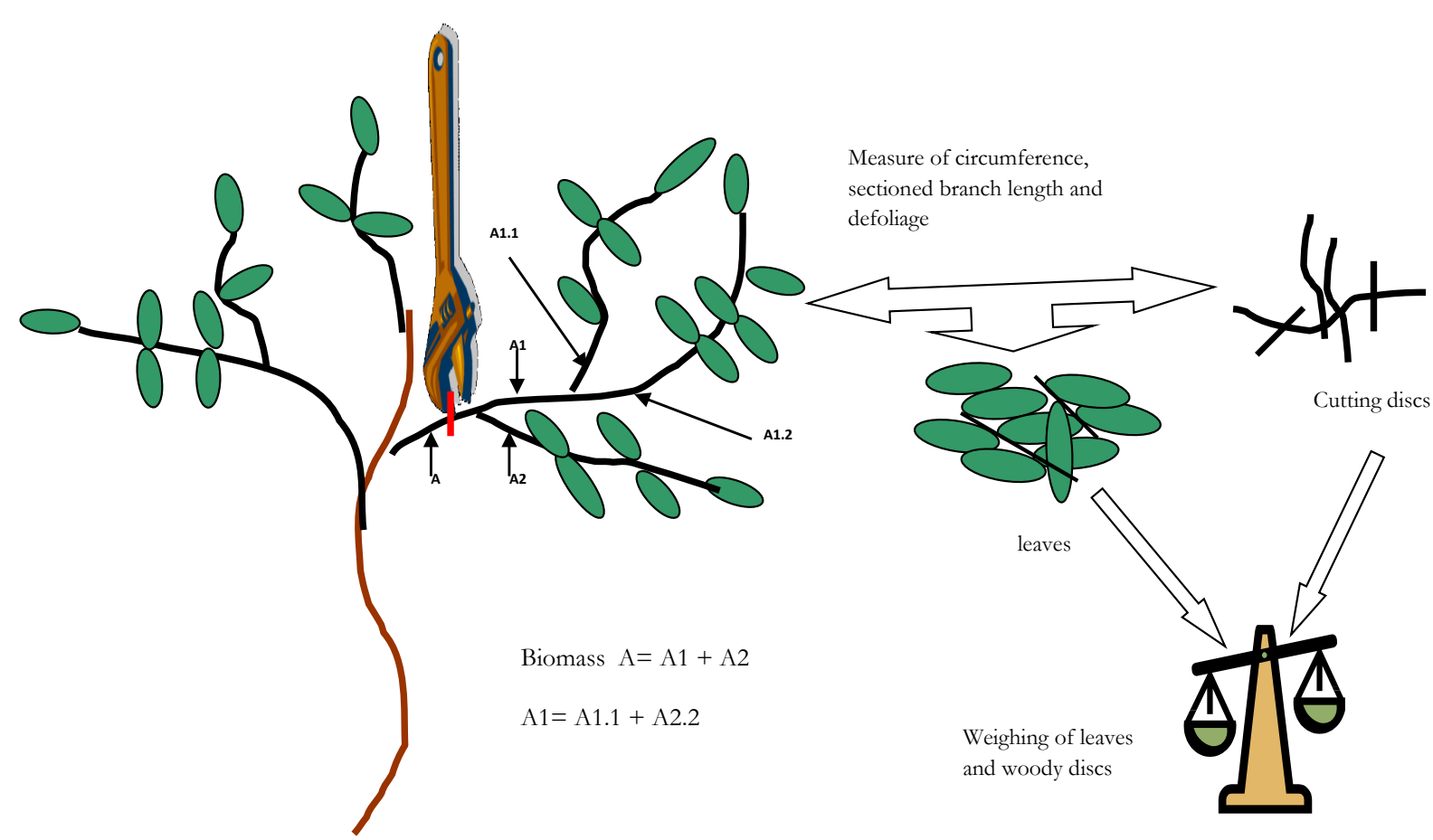

Figure 2. Principles of field leaves and ligneous biomass measurement.

$$
f(x)=\frac{c}{b}\left(\frac{x-a}{b}\right)^{C-1} \exp \left[-\left(\frac{x-a}{b}\right)^{c}\right]
$$

$\mathrm{a}=$ position parameter;

$\mathrm{b}=$ scale parameter or size parameter;

$\mathrm{c}=$ form parameter linked with the observed structure.

Trees circumference or trees height distribution were adjusted to Weibull function with Minitab 16 Software. The log-linear analysis [21] was performed for each case to test the adequacy of the observed structure to the Weibull distribution. The considered model described by [21] is Log Frequency $=\mathrm{F}+\mathrm{F} \_$class $+\mathrm{F} \_$Adjustment $+\varepsilon$.

$\mathrm{F}=$ mean frequency of the classes; $\mathrm{F}_{-}$Class $=$non-randomly gap linked to the differences in frequency between classes; $F_{\text {_Adjustment }}=$ non-randomly gap linked to differences between observed and theoretical frequencies; $\varepsilon$ is the error of the model. The hypothesis of adequacy between both distributions is accepted if the probability value of the test is higher than 0.05 .

Regressions on explanatory variables circumference and height were established to estimate the leaf biomass and wood biomass in Pterocarpus lucens. The strength of association between two variables was assessed by the coefficient of determination $\mathrm{R}^{2}$, between 0 and 1 .

This leads to allometric relationships of the following form:

- $\mathrm{Y}=\mathrm{aX}+\mathrm{b}$ or $\log _{10} \mathrm{Y}=\mathrm{a}+\mathrm{b} \log _{10} \mathrm{X}$ with $\mathrm{Y}$ is the leaf biomass (expressed in $\mathrm{g}$ of $\mathrm{DM}$ ), $\mathrm{X}$ is the circumference or the height (in $\mathrm{cm}$ ), $\mathrm{a}$ and $\mathrm{b}$ are constants.

- $\mathrm{Y}=\mathrm{aX}+\mathrm{bZ}+\mathrm{c}$ where $\mathrm{Y}$ is the wood dry matter (expressed in $\mathrm{kg}$ of $\mathrm{DM}$ ), $\mathrm{X}$ is the circumference, $\mathrm{Z}$ is the height (in $\mathrm{cm}$ ), a, b and c are constants. The principle of calculation of leaf biomass and wood biomass is to determine the distribution of size according to the classes in circumference at the base of the trunk. The regression equation is applied to the minimum and maximum value of each class of circumference. The values obtained for the leaf biomass and wood are weighted by the density of Pterocarpus lucens in each class. The average minimum and maximum values used to estimate forage production and the average amount of wood in $\mathrm{kg} \mathrm{DM} / \mathrm{ha}$. The amount of above ground sequestered carbon by Pterocarpus lucens is derived from the tree above ground biomass (wood biomass + leaf biomass) by multiplying by the factor 0.45 [22]. 


\section{Results}

\subsection{Structure of the Population of Pterocarpus lucens}

\subsubsection{Circumference Classes' Distribution of Pterocarpus lucens}

The circumference classes' distribution of Pterocarpus lucens adjusted to Weibull distribution showed bell-shaped form with left distribution $(1<\mathrm{c}<3.6)$ indicating a predominance of individuals with small circumference in the stand (Figure 3).

The first peak of the distribution of the population of Pterocarpus lucens by class circumference is represented by the class [30 - $40 \mathrm{~cm}$ ] constituted of individuals with small diameter. The second peak represented by two classes [50 - $60 \mathrm{~cm}]$ and $[60-70 \mathrm{~cm}]$ was comprised of individuals with average diameter. The third peak characterized by the class $[100-110 \mathrm{~cm}]$ consisted of individuals with large diameter.

The observed number of individuals in small classes [10 - $20 \mathrm{~cm}],[20-30 \mathrm{~cm}]$ and $[30-40 \mathrm{~cm}]$ showed a significant level of regeneration. Overall the structure reflected a relative balance of the population of Pterocarpus lucens.

\subsubsection{Total Height Classes' Distribution of Pterocarpus lucens}

The height classes' distribution of Pterocarpus lucens also showed bell-shaped form with left distribution $(1<\mathrm{c}$ $<3.6$ ) indicating a predominance of individuals with small height in the stand (Figure 4). The examination of the distribution of the height classes' distribution of Pterocarpus lucens population showed a bar bell with a peak class [4-5 m]. Individuals which height was between 2 and $7 \mathrm{~m}$ were more common as the population consisted of shrubs, the trees were rare. The small class sizes [0 - $1 \mathrm{~m}]$ and $[1-2 \mathrm{~m}]$ was due to the pressure on this species due to its palatability and frequency of bushfires. The significant level of regeneration revealed by the distribution of population circumference by class was only apparent, because the presence of low classes [0 $1 \mathrm{~m}]$ and [1 - $2 \mathrm{~m}$ ] showed that the renewal potential of Pterocarpus lucens was threatened.

\subsection{Dry Matter Content of the Leaf and Wood Biomass of Pterocarpus lucens}

The dry matter of 10 samples of wood and leaf biomass of Pterocarpus lucens were given in Table 1 . The dry matter content of the leaf biomass of Pterocarpus lucens was 56\% on average, but varied according to the samples with a minimum of $45 \%$ and up to $64 \%$. This variability was related to the diversity of geomorphological units with the resulting changes in soil water availability that is one of the main causes of the heterogeneity of leaves water content. The examination of the table showed that the dry matter content of wood varied little between $55 \%$ and $65 \%$ depending on the samples. The average dry matter content was $61 \%$, which was quite high,

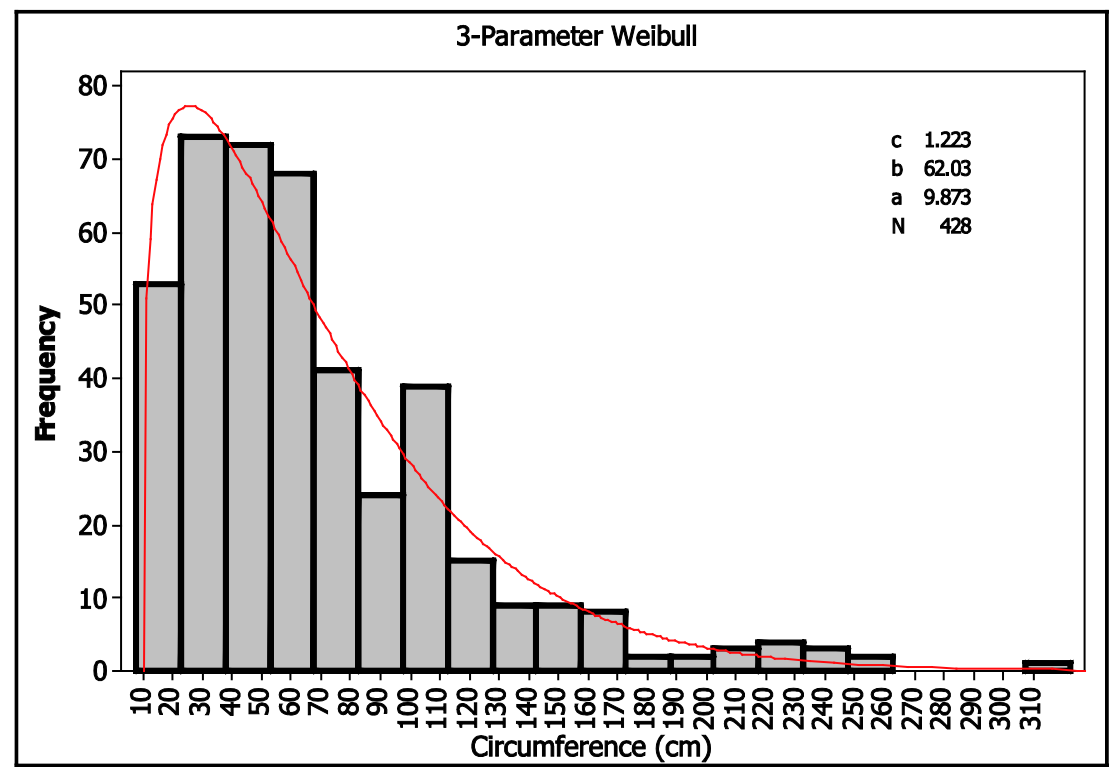

Figure 3. Circumference classes’ distribution of Pterocarpus lucens. 


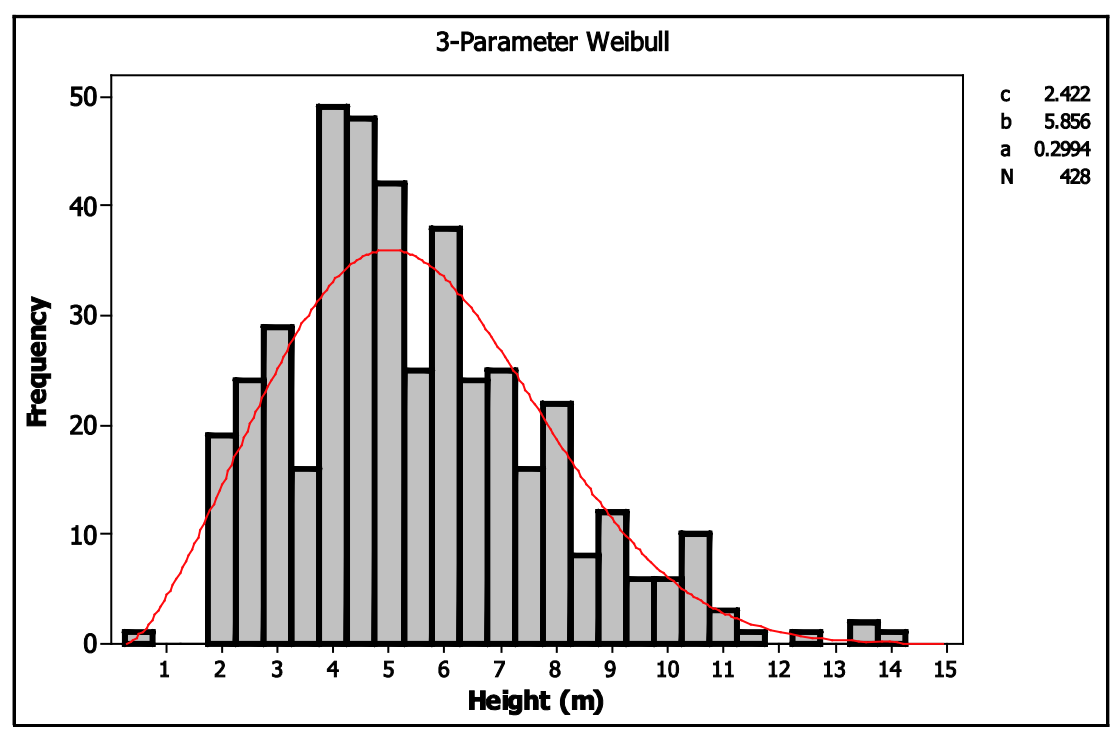

Figure 4. Height classes’ distribution of Pterocarpus lucens.

Table 1. Dry matter content of leaves and wood of Pterocarpus lucens.

\begin{tabular}{ccccc}
\hline \multirow{2}{*}{ Samples } & \multicolumn{2}{c}{ Leaf Biomass } & \multicolumn{2}{c}{ Ligneous Biomass } \\
\cline { 2 - 5 } & $\begin{array}{c}\text { DM } \\
\text { content \% }\end{array}$ & $\begin{array}{c}\text { Water } \\
\text { content } \%\end{array}$ & $\begin{array}{c}\text { DM } \\
\text { content } \%\end{array}$ & $\begin{array}{c}\text { Water } \\
\text { content \% }\end{array}$ \\
\hline 1 & 64 & 36 & 64 & 36 \\
2 & 58 & 42 & 65 & 35 \\
3 & 57 & 43 & 60 & 40 \\
4 & 45 & 55 & 59 & 41 \\
5 & 63 & 38 & 64 & 36 \\
6 & 57 & 43 & 59 & 41 \\
7 & 59 & 41 & 55 & 45 \\
8 & 55 & 45 & 60 & 40 \\
9 & 51 & 49 & 63 & 38 \\
10 & 51 & 49 & 58 & 39 \\
Mean & 56 & 44 & 61 & \\
\hline
\end{tabular}

that was explained by the fact that Pterocarpus lucens is a characteristic species of battleships in the Ferlo where water availability is lower.

\subsection{Modeling of Forage Production}

Allometric relationships between leaf biomass and circumference of Pterocarpus lucens were established. The prerequisites regressions were checked. Regression residuals were calculated and verified by the normality test of Ryan-Joiner ( $p \geq 0.01$ ). The assumption of independence of the residuals is also true ( $p \geq 0.05$ ). Furthermore the variance inflation factor of less than 10 indicated that predictors are not self-correlated. The method of forward selection allowed us to retain the only variable circumference having a regression coefficient highly significant $(\mathrm{p}=0.0001)$. Both the two studied models were shown in Table 2.

The examination of the curve of leaf biomass in function of the circumference (Figures 5 and 6) showed very satisfactory values for the coefficients of determination of the two models (74\% and 75\%). These high coefficients of determination showed that there was strong association between leaf biomass and basal circumference of trees.

Of all the tested models, the simple linear regression model was the most appropriate (Model 1). This model was used to calculate forage production of Pterocarpus lucens. 


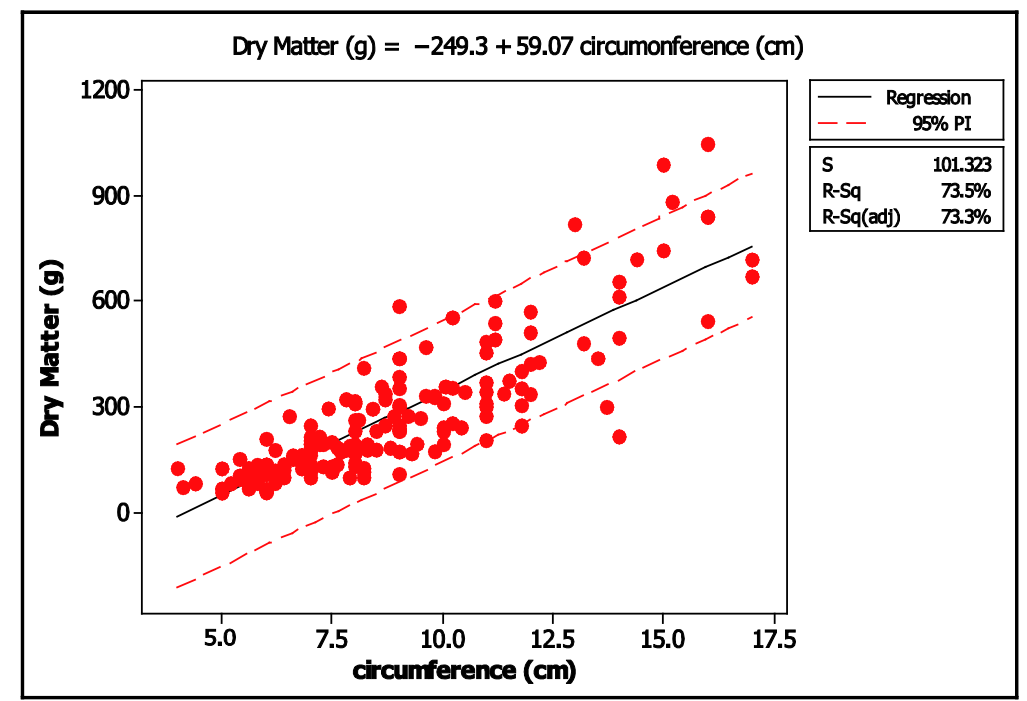

Figure 5. Simple linear regression of biomass in function of circumference.

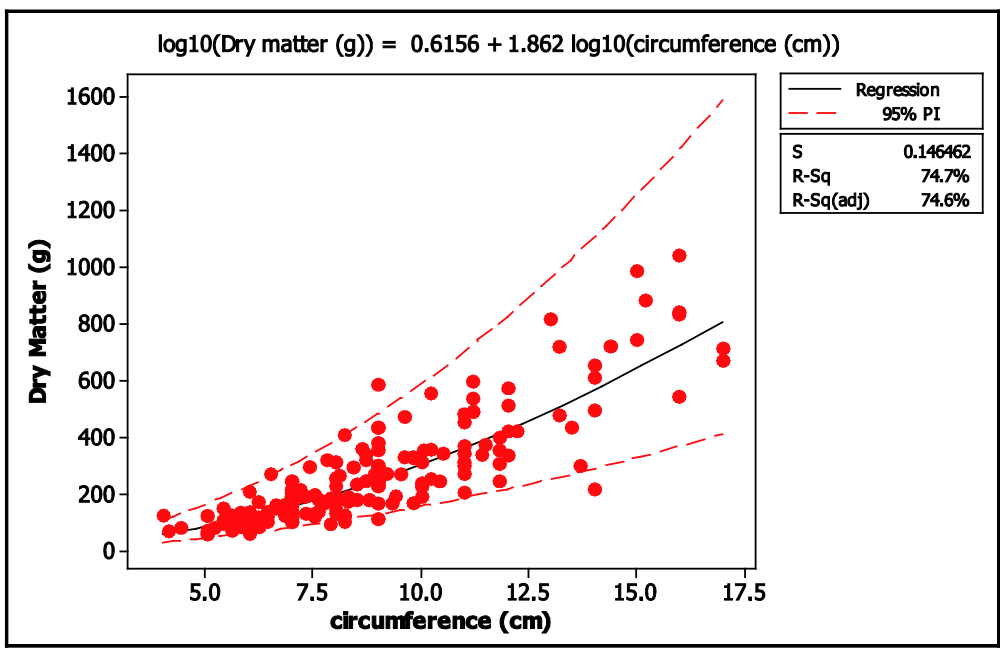

Figure 6. Logarithmic regression of biomass in function of circumference.

Table 2. Prediction models of leaves biomass in function of the circumference.

\begin{tabular}{ccc}
\hline Models & Regression equations & $\mathbf{R}^{2}$ \\
\hline Model 1 & Pf (g MS) $=-249.3+59.07$ C $(\mathrm{cm})$ & $74 \%$ \\
Model 2 & $\log 10 \mathrm{Pf}\left(\mathrm{g}\right.$ MS) $=0.6156+1.862 \log _{10} \mathrm{C}(\mathrm{cm})$ & $75 \%$ \\
\hline
\end{tabular}

$\mathrm{Pf}=$ Forage production in $\mathrm{g}$ of $\mathrm{DM} ; \mathrm{C}=$ Circumference in $\mathrm{cm} ; \mathrm{R}^{2}=$ coefficient of determination.

\subsection{Modeling the Wood Production}

The dendrometric characteristics (length and circumference) and branch discs weight were the variables that have enabled us to establish an allometric model to calculate the wood biomass of Pterocarpus lucens (Figure 7). The model of wood dry matter content estimation was globally very highly significant as well as its parameters. The model is as follows:

$\mathrm{P}(\mathrm{kg} \mathrm{DM})=-1.77+0.150 \mathrm{C}(\mathrm{cm})+0.506 \mathrm{H}(\mathrm{m}) \mathrm{R}^{2}=76 \%$ with $\mathrm{P}=$ timber production in kg dry matter $\mathrm{C}=$ circumference of $0.3 \mathrm{~m} \mathrm{~cm} \mathrm{H}=$ height of the tree $\mathrm{R}^{2}=$ coefficient of determination.

The coefficient of determination of the model of $76 \%$ was high. It showed that there was a high correlation between the wood production, the circumference and length of the branches. 


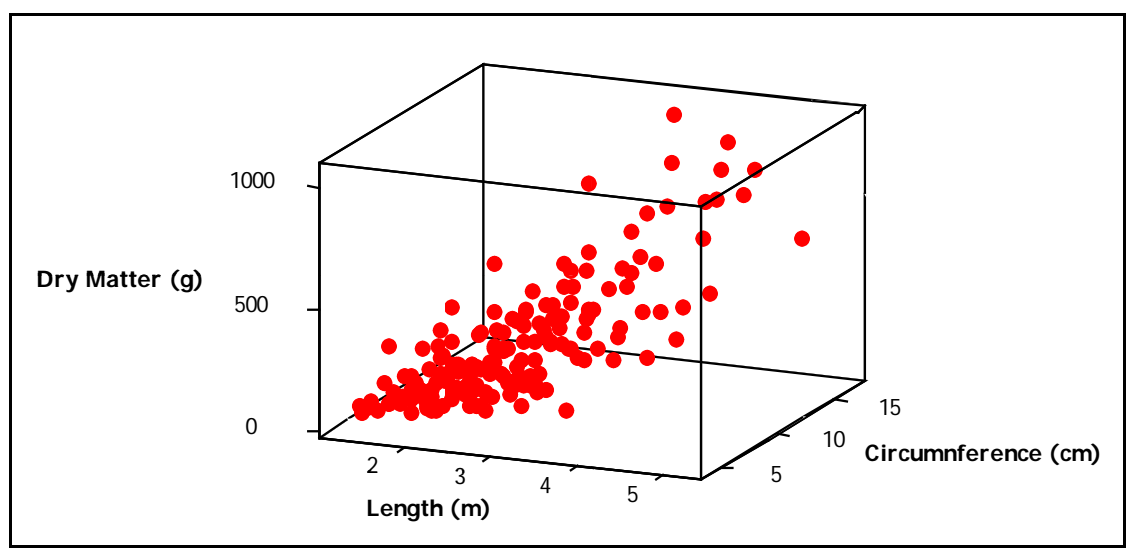

Figure 7. 3D tendency of wood biomass in function of circumference and branches length.

\subsection{Estimation of Forage Production}

The simple linear regression model was more appropriate to calculate forage production, $\mathrm{Pf}$ ( $\mathrm{g} \mathrm{DM})=-249.3+$ $59.07 \mathrm{C}(\mathrm{cm})$. This equation was used to calculate the minimum and maximum values of leaf biomass in different circumference classes in $\mathrm{kg} \mathrm{DM} / \mathrm{ha}$ (Table 3 ).

The average minimum and maximum values of the different classes of circumference allowed calculating the usable forage production (Kg DM/ha) of Pterocarpus lucens.

$\Sigma$ Minimum values $=144.3 \mathrm{~kg} \mathrm{DM} / \mathrm{ha}$

$\Sigma$ Maximum values $=211.4 \mathrm{~kg} \mathrm{DM} / \mathrm{ha}$

Average forage production $\mathrm{Pf}=(\Sigma$ values min $+\Sigma$ values max $) / 2=178 \mathrm{~kg} \mathrm{DM} / \mathrm{ha}$

Forage production of Pterocarpus lucens is between 144.3 and $211.4 \mathrm{~kg} \mathrm{DM} / \mathrm{ha}$. The ratio between the average maximum and minimum average is not high (1.5) which can be explained by the presence in the stand of all classes of circumference.

\subsection{Estimation of Firewood Production}

The regression on the explanatory variables circumference and height has established a model to predict the production of wood in Pterocarpus lucens. This model is as follows: $\mathrm{Pb}(\mathrm{kg} \mathrm{DM})=-1.77+0.150 \mathrm{C}(\mathrm{cm})+$ $0.506 \mathrm{H}(\mathrm{m})$

Based on this model we calculated the minimum and maximum values of the wood production in the different classes of circumference kg DM/ha (Table 4).

\subsection{Quantification of Sequestered Carbon}

The developed allometric equations were used to calculate the leaf and wood biomass of Pterocarpus lucens. To estimate the amount of above ground sequestered carbon, tree above ground biomass (wood biomass + leaf biomass) was multiplied by the factor 0.45 [22] [23]. The amount of sequestered carbon is: $0.45 \times(178 \mathrm{~kg}+545$ $\mathrm{kg}) / \mathrm{ha}$.

Amount of above ground sequestered carbon $=325.35 \mathrm{~kg} \mathrm{C} / \mathrm{ha}$.

\section{Discussion}

The aim of this work was to quantify the most important ecosystem services such as forage, wood biomass and the amount of sequestered carbon provided by Pterocarpus lucens in the Biosphere Reserve of Ferlo. Thus, from allometric relationships on variables circumference and height, we estimated the production of forage, timber and the amount of sequestered carbon in Pterocarpus lucens. The assessment of forage production is complex. The difficulty to access plant biomass as well as its spatial and temporal variability is probably partly responsible for the late development of assessment methods for forage phytomass evaluation [24]. Thus, due to the destructive and fastidious direct measurements of plant biomass, the research of allometric relationships between 
Table 3. Forage production estimation according to circumference classes.

\begin{tabular}{rcc}
\hline \multicolumn{1}{c}{ Circumference classes $(\mathrm{cm})$} & Pf (Kg DM/ha) \\
\hline$[10-20]$ & $\min$ & 1.45 \\
& $\max$ & 3.95 \\
{$[20-30]$} & $\min$ & 4.31 \\
& $\max$ & 6.61 \\
{$[30-40]$} & $\min$ & 9.75 \\
& $\max$ & 13.02 \\
{$[40-50]$} & $\min$ & 7.02 \\
& $\max$ & 8.74 \\
{$[50-60]$} & $\min$ & 13.40 \\
& $\max$ & 15.98 \\
{$[60-70]$} & $\min$ & 14.91 \\
& $\max$ & 17.27 \\
{$[70-80]$} & $\min$ & 8.77 \\
& $\max$ & 9.95 \\
{$[80-90]$} & $\min$ & 8.25 \\
& $\max$ & 9.21 \\
{$[100-100]$} & $\min$ & 11.91 \\
& $\max$ & 13.14 \\
& $\min$ & 36.38 \\
& $\max$ & 54.80 \\
& $\min$ & 28.22 \\
& $\max$ & 58.77 \\
\hline & & \\
& &
\end{tabular}

Table 4. Estimation of wood production according to circumference and height classes.

\begin{tabular}{|c|c|c|c|}
\hline Circumference (cm) & Mean of height & \multicolumn{2}{|c|}{ Wood biomass (Kg DM/ha) } \\
\hline \multirow{2}{*}[10-20]{} & \multirow{2}{*}{3.20} & $\min$ & 5.72 \\
\hline & & $\max$ & 12.09 \\
\hline \multirow{2}{*}[20-30]{} & \multirow{2}{*}{4.00} & $\min$ & 14.79 \\
\hline & & $\max$ & 20.65 \\
\hline \multirow{2}{*}[30-40]{} & \multirow{2}{*}{4.30} & $\min$ & 31.15 \\
\hline & & $\max$ & 39.47 \\
\hline \multirow{2}{*}[40-50]{} & \multirow{2}{*}{4.70} & $\min$ & 21.84 \\
\hline & & $\max$ & 26.21 \\
\hline \multirow{2}{*}[50-60]{} & \multirow{2}{*}{4.90} & $\min$ & 40.53 \\
\hline & & $\max$ & 47.08 \\
\hline \multirow{2}{*}[60-70]{} & \multirow{2}{*}{5.70} & $\min$ & 45.62 \\
\hline & & $\max$ & 51.62 \\
\hline \multirow{2}{*}[70-80]{} & \multirow{2}{*}{5.70} & $\min$ & 26.14 \\
\hline & & $\max$ & 39.30 \\
\hline \multirow{2}{*}{ [80-90] } & \multirow{2}{*}{6.40} & $\min$ & 39.74 \\
\hline & & $\max$ & 43.68 \\
\hline \multirow{2}{*}{ [90-100] } & \multirow{2}{*}{6.60} & $\min$ & 35.36 \\
\hline & & $\max$ & 38.50 \\
\hline \multirow{2}{*}[100-150]{} & \multirow{2}{*}{7.60} & $\min$ & 109.62 \\
\hline & & $\max$ & 156.39 \\
\hline \multirow{2}{*}{$>150$} & \multirow{2}{*}{9.70} & $\min$ & 83.84 \\
\hline & & $\max$ & 161.42 \\
\hline
\end{tabular}


leaf biomass and various physical parameters (height and girth) easily measurable emerged as an interesting method at any point of view. Indeed, the allometric relationships have been studied in multiple works on different species as well in Sahelian ecosystems [25]-[31] as in temperate ecosystems [32]-[35]. The modeling of forage production in this study revealed that among the two physical parameters studied, the circumference has a better correlation with biomass. These results support the work of Cissé [27] and [30]. Also the circumference at the base is easier to measure in the field data. The proposed model was used to calculate forage production of Pterocarpus lucens is estimated at $178 \mathrm{~kg} / \mathrm{ha}$. This value is four times greater than that found by Ngom et al., [30] in other ecosystems in the Ferlo which is explained by a higher density (43 individuals/ha) but also by an improved calculation method which takes into account the density of class circumference and not the overall density. The importance of this forage production confirms the dominant position occupied by woody forage in livestock feed in the Sahel. Wood biomass was also calculated from an allometric relationship that takes into account both the circumference and the tree height. Timber production of Pterocarpus lucens is estimated in the Biosphere Reserve of Ferlo at $545 \mathrm{~kg} \mathrm{DM} / \mathrm{ha}$. These results are interesting in practice in a context of increasing rural demand for forest products (firewood, timber service). Today, the challenge of sustainable management of the Ferlo sylvo-pastoral ecosystems in general and the Biosphere Reserve in particular is to balance production with the needs of populations. For this, it is imperative to know the potential production of these ecosystems. According to Ngom [3], Pterocarpus lucens is exploited in Ferlo. Besides its importance as firewood, it is the most used species as wood construction and one of the two most palatable species to livestock, but also the most pruned by the shepherds [36]. The challenge for management is to reconcile the maintenance of the potential of this forage species with increasing grazing pressure [37]. Tree above ground biomass was used to calculate the amount of above ground sequestered carbon in Pterocarpus lucens in the Biosphere Reserve of Ferlo. In fact, this species is capable of storing $325.35 \mathrm{~kg} \mathrm{C} / \mathrm{ha}$. The measurement of carbon in tropical lands has become important in studies of global climate change because carbon lost by tropical systems contributes significantly to atmospheric changes and in particular the increase of $\mathrm{CO}_{2}$ [38]. Indeed, the main way to reduce net carbon emissions is to increase the amount of sequestered carbon by terrestrial ecosystems [39]. The presence of high densities of trees in the Biosphere Reserve of Ferlo effectively contributes to the production of organic carbon and humus promotes maximum production if the appropriate management techniques are applied leading to a maximum biomass production [40].

Thus, to evaluate the potential forage, timber production and the amount of sequestered carbon in the Sahelian species, the use of regression equations can reduce the human and financial costs of such an operation. However, any extrapolation to a larger scale remains very uncertain. Indeed, most of the factors that affect the productivity of vegetation vary from one study to another. Also, interspecific differences, the conditions of the water supply, the potential of the soil and climate are especially never identical from one station to another [34]. It is also established that the allometric equations vary depending on the age of the plant phenology and grazing pressure [27] [41] [42]. The transfer of the proposed models to other regions must be done carefully. Many parameters must be taken into account in establishing the production models such as the state of the tree and the soil type [43]. A great accuracy is generally not attainable with allometric equations.

However, the prediction formulas are a contribution to the thorny problem of reliable assessment of the production of wood, leaf biomass and the amount of sequestered carbon by a forage species in the Sahel. Indeed, the capacity to model and to predict the evolution of sylvo-pastoral resources is an important issue for biosphere reserves in the Sahel.

\section{References}

[1] Akpo, L.E., Banoin, M. and Grouzis, M. (2003) Effet de l'arbre sur la production et la qualité fourragères de la végétation herbacée: Bilan pastoral en milieu sahélien. Revue d'éLevage et de Médecine Vétérinaire des Pays Tropicaux, 154, 619-628.

[2] Le Houerou, H.N. (1980) Le rôle des ligneux fourragers dans les zones sahélienne et soudanienne. Les fourrages ligneux en Afrique: état actuel des connaissances, 85-101.

[3] Ngom, D. (2008) Définition d’indicateurs de gestion durable des ressources sylvo-pastorales au Ferlo (Nord-Sénégal). Thèse de Doctorat en Biologie végétale, Faculté des Sciences et Techniques, Université Cheikh Anta Diop de Dakar, Dakar, 148 p.

[4] Clement, J. (1982) Estimation des volumes et de la productivité des formations mixtes forestières et graminéennes tropicale. Bois et Forêts des Tropiques, 198, 35-58. 
[5] FAO (1984) Études sur les volumes et la productivité des peuplements forestiers tropicaux. 1. For mations forestières sèches, Rome, Italie, FAO, Série Étude FAO: Forêts No 51/1, 88 p.

[6] Nouvellet, Y. (1992) Evolution d'un taillis de formation naturelle en zone soudanienne du Burkina Faso. Thèse de Doctorat en Botanique Tropicale. Université Pierre et Marie Curie, Paris, 356 p.

[7] Nasi, R. (1994) La végétation du Centre Régional d'endémisme soudanien au Mali. Etude de laforêt des monts mandingues et essai de synthèse. Thèse Doct. Sci.. Paris Sud, 175 p + ann.

[8] Sylla, M.L. (1997) Evaluation rapide de la productivité et de la production des formations végétales: bassins de Bamako et de Ségou. Rapport de mission. République du Mali/MDRE/DNAER, 27 p.

[9] Picard, N., Ballo, M., Dembele, F., Gautier, D., Kaïre, M., Karembe, M., Mahamane, A., Manlay, R., Ngom, D., Ntoupka, M., Ouattara, S., Savadogo, P., Sawadogo, L. and Seghieri, J. (2006) Evaluation de la productivité et de la biomasse des savanes sèches africaines: l’Apport du collectif SAVAFOR. Bois et Forêts des Tropique, 288, 75-80.

[10] Coulibaly, S.M. (1998) Détermination de la productivité des jachères dans la zone de Ouellessebougou. Mémoire de fin de cycle. Institut Polytechnique Rural de Formation et de Recherche Appliquée (IPR/IFRA), Katibougou, Mali, 67 p.

[11] Cornet, A. (1992) Relation entre la structure spatiale des peuplements végétaux et le bilan hydrique des sols de quelques phytocénoses en zone aride. L’aridité une contrainte au développement, ORSTOM, Editions, 245-263.

[12] Roussel, J. (1995) Pépinières et plantations forestières en Afrique tropicale sèche. Editions, ISRA, CIRAD, 435p.

[13] Arbonnier, M. (2002) Arbres. arbustes et lianes des zones sèches d'Afrique de l'Ouest. CIRAD et Museum d'histoire naturel de Paris, 573 p.

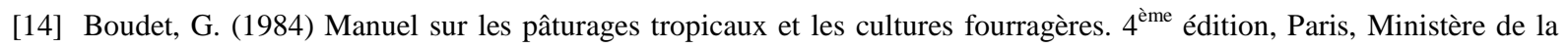
Coopération, Manuel et Précis d'élevage 4, 254p.

[15] Akpo, L.E. and Grouzis, M. (1996) Influence du couvert sur la régénération de quelques espèces ligneuses sahéliennes (Nord-Sénégal, Afrique occidentale). Webbia, 50, 247-263. http://dx.doi.org/10.1080/00837792.1996.10670605

[16] Newbould, J.P. (1967) Methods for estimating the primary production of forest. Blackwell, Oxford, $62 \mathrm{p}$.

[17] Bailey, R.L. and Dell, T.R. (1973) Quantifying Diameter Distributions with the Weibull Function. Journal of Forest Science, 19, 97-104.

[18] Rondeux, J. (1993) Les Mesures des Arbres et Des Peuplements Forestiers,” Presses Agronomiques de Gembloux, Gembloux, 521.

[19] Bonou, W., Glele-kakai, R., Assogbadjo, A.E., Fonton, H.N. and Sinsin, B. (2009) Characterization of Afzelia africana Sm. Habitat in the Lama Forest Reserve of Benin. Forest Ecology and Management, 258, 1084-1092. http://dx.doi.org/10.1016/j.foreco.2009.05.032

[20] Diallo, A., Agbangba, E.C., Ndiaye, O. and Guisse, A. (2013) Ecological Structure and Prediction Equations for Estimating Tree Age and Dendometric Parameters of Acacia senegal in the Senegalese Semi-Arid Zone Ferlo. American Journal of Plant Sciences, 4, 1046-1053. http://dx.doi.org/10.4236/ajps.2013.45129

[21] Caswell, H. (2001) Matrix Population Models: Construction Analysis and Interpretation. 2nd Edition, Sinauer Associates, Sunderland.

[22] Woomer, P.L. and Palm, C. (1998) An Approach to Estimating System Carbon Stocks in Tropical Forests and Associated Land Uses. Commonwealth Forestry Review, 77, 181-190.

[23] Woomer, P.L., Toure, A. and Sall, M. (2004) Carbon Stocks in Senegal's Sahel Transition Zone. Journal of Arid Environments, 59, 499-510. http://dx.doi.org/10.1016/j.jaridenv.2004.03.027

[24] Ickowicz, A. (1995) Approche dynamique du bilan fourrager appliqué à des formations pastorales du sahel tchadien. Thèse, Université de Paris XII, Créteil, 472 p.

[25] Poupon, H. (1976) La biomasse et l'évaluation de la répartition au cours de la croissance d'Acacia senegal dans une savane sahélienne. Revues Bois et forêts des tropique, 166, 23-38.

[26] Bille, J.C. (1977) Etude de la production primaire nette d’un écosystème sahélien. Travaux et Documents, ORSTOM, Paris.

[27] Cisse, M.I. (1980) Production fourragère de quelques arbres sahéliens: Relations entre la biomasse foliaire et divers paramètres physiques. In: Les fourrages ligneux en Afrique: Etat actuel des connaissances, CIPEA, Addis Abeba, 203-208.

[28] Piot, J., Nebout, J.P., Nanot, R. and Toutain, B. (1980) Utilisation des ligneux sahéliens par les herbivores domestiques. Etude quantitative dans la zone sud de la mare d'oursi (Haute Volta), IEMVT, CTFT, 217 p.

[29] Claude, J., Grouzis, M. and Milleville, M. (1992) Un espace sahélien. In: La mare d’Oursi, Ed., ORSTOM, Paris, 241 p. 
[30] Ngom, D., Diatta, S. and Akpo, L.E. (2009) Estimation de la production fourragère de deux ligneux sahéliens (Pterocarpus lucens Lepr. Ex Guill. \& Perrot et Grewia bicolor Juss) au Ferlo (Nord Sénégal). Livestock Research for Rural Development, 21, 1-8.

[31] Ould Soule, A. (2011) Les caractéristiques écologiques de Ziziphus mauritiana LAM dans le sud mauritanien. Doctorat $3^{\text {ème }}$ cycle en Biologie végétale, UCAD, 103 p.

[32] Pressland, A.J. (1975) Productivity and Management of Mulga in South-Western Queensland in Relation to Tree Structure and Density. Australian Journal of Botany, 23, 965-976.

[33] Phillips, D.R. (1977) Total Tree Weights and Volumes for Understory Hardwoods. TAPPI, 60, 68-71.

[34] Cabanettes, A. and Rapp, M. (1978) Biomasse, minéralomasse et productivité d’un écosystème à Pins pignons (Pinus pinea L) du littoral méditérranéen. Revue Ecologia Plantarum, Tome, 13, 271-286.

[35] Auclair, D. and Metayer, S. (1980) Méthodologie de l'évaluation de la biomasse aérienne sur pied et de la production en biomasse des taillis. Revue Acta Ecologica, 1, 357-377.

[36] Ngom, D., Bakhoum, A., Kindomihou, V., Diatta, S. and Akpo, L.E. (2012) Firewood potential production of three sahelian woody species (Grewia bicolor. Pterocarpus lucens and Combretum glutinosum) in Ferlo (Northern Senegal). Rev. Advances in Environmental Biology, 6, 2329-2337.

[37] Couteron, C., d’Aquino, P. and Ouedraogo, I.M.O. (1992) Pterocarpus lucens Lepr. Dans la région de Banh (nordouest du Burkina Faso. Afrique occidentale). Importance pastorale et état actuel des peuplements. Revue d'élevage et de médecine vétérinaire des pays tropicaux, 45, 179-190.

[38] Woomer, P.L. (2001) Caractérisation du carbone dans la végétation et dans les sols en champs et en laboratoire. Communication à l'atelier de travail sur l'échantillonnage du carbone environnemental et la modélisation biogéochimique, Dakar, 23 p.

[39] Lipper, L., Dutilly-Diane, C. and Mccarty, N. (2010) Supplying Carbon Sequestration from West African Rangelands: Opportunities and Barriers. Rangeland Ecology \& Management, 63, 155-166. http://dx.doi.org/10.2111/REM-D-09-00009.1

[40] Baumer, M. (1997) L'agroforesterie pour les productions animales. CTA, ICRAF, Van Ruys Bruxelles, 340 p.

[41] Azocar, P., Lailhacar, S., Padilla, F. and Rojo, H. (1991) Méthode d'évaluation de la phytomasse utilisable des arbustes fourragers Atriplex repanda et Flourensia thurifera. In: Kernick, G.A.M. and Le Houerou, H.N., Eds., Iv congres international des terres de parcours, Montpellier, 512-514.

[42] Oba, G. (1991) An Evaluation Technique for Predicting Phytomass of indigofera spinosa (forsk) on a Semi-Desert Range, kenya. In: Gaston, A., Kernick, M. and Le Houerou, H.N., Eds., Iv ${ }^{e}$ congres international des terres de parcours, Montpellier, 333-335.

[43] Manlay, R., Peltier, R., Ntoupka, M. and Gautier, D. (2002) Bilan des ressources arborées d'un village de savane soudanienne au Nord Cameroun en vue d'une gestion durable. In: Jamin, J.Y. and Seiny Boukar, L., Eds., Savanes africaines: Des espaces en mutation des acteurs face à de nouveaux défis, Actes du colloques, Mai, Maroua, 15 p. 